\title{
Medicine waste disposal
}

\section{KEY POINTS}

- Waste must be segregated correctly

- Learn the key colours for hazardous (yellow, orange and purple) and non-hazardous (blue and black) waste

- Ensure all segregated waste is correctly labelled with the legally required European Waste Catalogue (EWC) and Hazardous Property (HP) codes where applicable

- Use the appropriate terminology - healthcare waste: medicinal, non-hazardous or hazardous.

- Ensure all staff are properly trained for correct waste segregation

Medicinal waste disposal is an important part of healthcare waste management within a veterinary practice. It should be incorporated into the scheme of work (known as the Pre-Acceptance Audit*) for healthcare waste management; the rules and requirements are relevant across the waste management requirements within the practice.

Additional sources of information that will help shape the management of medicinal waste include:

- British Veterinary Association (BVA) Waste Guidelines

- Department of Health and Social Care guidance booklet Safe Management of Healthcare Waste

- The practice's waste contractor's systems and processes.

Veterinary surgeons (veterinarians) are advised to start with the veterinary guidelines. If these, or the other sources of information mentioned above, do not answer any queries the practice may have regarding medicine waste disposal, advice from the Department of Health and Social Care or BVA or waste contractor should be sought.

* Pre-Acceptance Audit is also known as the Pre-Collection Audit and is now the commonly used terminology.

\section{Waste segregation}

The key component of veterinary healthcare waste management is segregation. Waste must be designated to special bins and disposed of according to strict guidelines.

\section{Types of Disposal}

\begin{tabular}{|c|c|c|c|c|}
\hline Waste type & Colour & Disposal type & Notes & Code \\
\hline $\begin{array}{l}\text { Hazardous } \\
\text { waste }\end{array}$ & Yellow & $\begin{array}{l}\text { For highly regulated, high } \\
\text { temperature specialist } \\
\text { incineration }\end{array}$ & $\begin{array}{l}\text { Individual bin consignment } \\
\text { paperwork and additional } \\
\text { tax payment }\end{array}$ & $\begin{array}{l}180202 \text { plus } \\
\text { relevant HP code }\end{array}$ \\
\hline $\begin{array}{l}\text { Hazardous } \\
\text { waste }\end{array}$ & Orange & $\begin{array}{l}\text { For highly regulated, specialist } \\
\text { processing but slightly less } \\
\text { costly because of avoidance of } \\
\text { specialist incineration }\end{array}$ & $\begin{array}{l}\text { Individual bin consignment } \\
\text { paperwork and additional } \\
\text { tax payment }\end{array}$ & $\begin{array}{l}180202 \text { plus } \\
\text { relevant HP code }\end{array}$ \\
\hline $\begin{array}{l}\text { Hazardous } \\
\text { medicinal waste }\end{array}$ & Purple & $\begin{array}{l}\text { For highly regulated, high } \\
\text { temperature specialist } \\
\text { incineration }\end{array}$ & $\begin{array}{l}\text { Individual bin consignment } \\
\text { paperwork and additional } \\
\text { tax payment }\end{array}$ & $\begin{array}{l}180207 \text { plus } \\
\text { relevant HP code }\end{array}$ \\
\hline $\begin{array}{l}\text { Non-hazardous } \\
\text { medicinal waste }\end{array}$ & Blue & $\begin{array}{l}\text { For regulated specialist } \\
\text { incineration }\end{array}$ & $\begin{array}{l}\text { Annual paperwork } \\
\text { recording }\end{array}$ & 180208 \\
\hline Offensive waste & $\begin{array}{l}\text { Yellow/ } \\
\text { Black } \\
\text { Striped }\end{array}$ & $\begin{array}{l}\text { For deep land-fill or incineration } \\
\text { for energy }\end{array}$ & $\begin{array}{l}\text { Not applicable to medicinal } \\
\text { waste } \\
\text { Annual paperwork } \\
\text { recording }\end{array}$ & 180203 \\
\hline Domestic waste & $\begin{array}{l}\text { Black or } \\
\text { recycling }\end{array}$ & $\begin{array}{l}\text { For recycling, land-fill or } \\
\text { incineration for energy }\end{array}$ & $\begin{array}{l}\text { Annual paperwork } \\
\text { recording }\end{array}$ & $\begin{array}{l}\text { Dependent on } \\
\text { waste type (e.g. } \\
\text { cardboard 150101) }\end{array}$ \\
\hline
\end{tabular}




\section{Colour coding}

Although not a strict legal requirement, the UK has devised a colour coding system to help ensure the correct waste is disposed via the correct waste stream.

\section{UK healthcare waste colour coding}

\begin{tabular}{|c|c|c|c|}
\hline Colour & Hazardous/non-hazardous & Contents & Notes \\
\hline Yellow & $\begin{array}{l}\text { Hazardous waste for } \\
\text { incineration }\end{array}$ & $\begin{array}{l}\text { Any waste that is deemed } \\
\text { to fall into definition laid } \\
\text { out in the hazardous } \\
\text { property codes (@) }\end{array}$ & $\begin{array}{l}\text { Medicinal hazardous waste is mainly } \\
\text { purple waste. HP9 (infectious) waste is } \\
\text { the most relevant code. No medicines in } \\
\text { this stream. All hazardous wastes cannot } \\
\text { be moved between branches }\end{array}$ \\
\hline Orange & $\begin{array}{l}\text { Hazardous waste for } \\
\text { treatment prior to disposal }\end{array}$ & $\begin{array}{l}\text { Any waste that is deemed } \\
\text { to fall into definition laid } \\
\text { out in the hazardous } \\
\text { property codes (@) }\end{array}$ & $\begin{array}{l}\text { Treatments include autoclaving or } \\
\text { disinfection. No medicines in this stream. } \\
\text { All hazardous wastes cannot be moved } \\
\text { between branches }\end{array}$ \\
\hline Purple & Hazardous medicinal waste & $\begin{array}{l}\text { Cytotoxic or cytostatic } \\
\text { medicines or items } \\
\text { contaminated with these }\end{array}$ & $\begin{array}{l}\text { All hazardous wastes cannot be moved } \\
\text { between branches }\end{array}$ \\
\hline $\begin{array}{l}\text { Blue (the 'pha } \\
\text { bin') }\end{array}$ & $\begin{array}{l}\text { Non-hazardous medicinal } \\
\text { waste }\end{array}$ & Medicines & $\begin{array}{l}\text { Denatured Controlled Drugs in this } \\
\text { stream }\end{array}$ \\
\hline $\begin{array}{l}\text { Black and yell } \\
\text { stripes }\end{array}$ & $\begin{array}{l}\text { Non-hazardous offensive } \\
\text { waste }\end{array}$ & $\begin{array}{l}\text { Veterinary blood, body } \\
\text { fluid or excrement } \\
\text { contaminated waste }\end{array}$ & No medicines in this stream \\
\hline Black & Domestic waste & Packaging & $\begin{array}{l}\text { Packaging must not be contaminated. } \\
\text { Recycle where possible }\end{array}$ \\
\hline
\end{tabular}

\section{Bins}

\section{Pharmaceutical waste bin - non-hazardous}

The pharmaceutical waste disposal bin, also known as the 'pharmy bin', is the main disposal bin for pharmaceutical waste. The contents of the bin should be recorded and the record made available to the disposal contractor. Exemption exists for low volume disposals, but it is good practice to keep a record. A dummy client file on the practice management system, either computerized or manual, could be created for this purpose. The date, type and amount of medicine is logged. Computerized practices will automatically 'destock'. A printout or photocopy of the record is the basis of the contents list of the pharmaceutical waste bin, along with a list of any medicines returned by the clients. This information is an important component of the medicine audit.

The pharmaceutical waste bin should be blue leak-proof plastic*, EWC code 1802 08. The contents of this bin should be non-hazardous and include:

- Vaccine bottles

- Empty injection bottles (not cytotoxic/cytostatic medicines)

- Syringes (not cytotoxic/cytostatic medicines)

- Whole medicines (not cytotoxic/cytostatic medicines)

- Denatured Controlled Drugs.

All syringes placed in the bin should have been fully discharged of content. Snap-top glass vials should not be placed in these bins; they should be placed in the sharps bin.

* Availability of blue containers is unpredictable so they might be supplied as yellow or yellow with a blue lid but that does not mean they are hazardous wastes!

\section{Sharps}

The sharps bin should be yellow, orange or purple, which indicates 'hazardous waste'. Bins must comply with the British Standard 7320:1990; EWC codes are 180202 (yellow/ orange) and 180207 (purple). Cytotoxic/ cytostatic waste should be segregated to purple sharps bins. Other waste should be disposed of in yellow or orange bins depending on the method of disposal. Content of sharps bins includes:
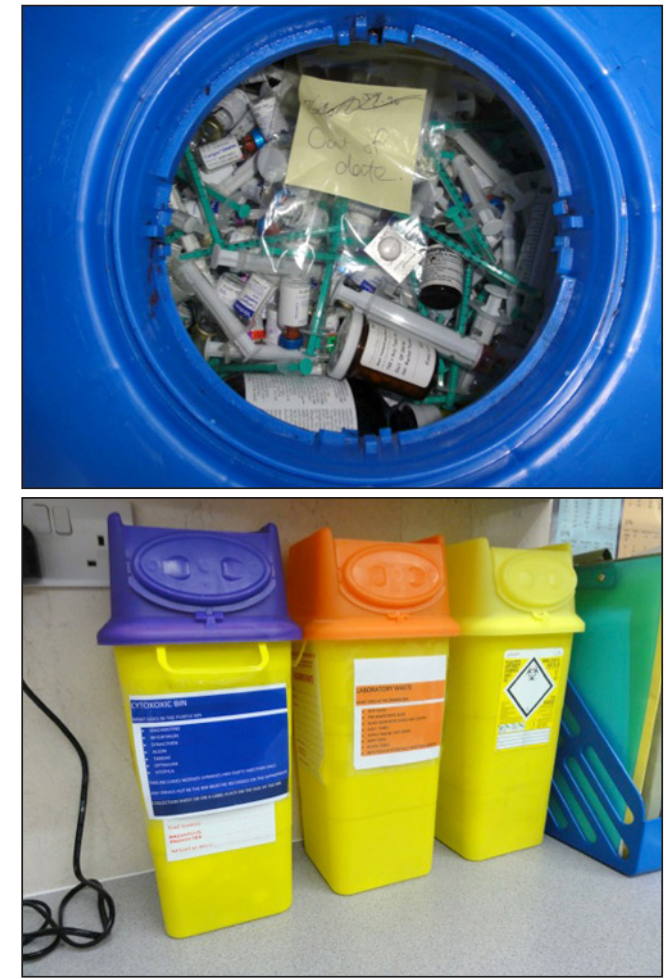
- Used needles

- Glass vials

- The purple bin may also be used for other cytotoxic/cytostatic waste

- Empty injection bottles

- Syringes

- Whole medicine

- Other items contaminated with cytotoxic/cytostatic medicines (e.g. giving sets)

- Any materials used for mopping up spills, contaminated gloves and contaminated dressings.

\section{Domestic waste}

Domestic waste should be placed in a black bag and put out for regular collections. Where possible, waste should be recycled. Medicine packaging must not contain any traces of medicine or have been in direct contact with the medicine. Medicinal 'domestic' waste includes:

- Non-contaminated paper

- Non-contaminated card

- Non-contaminated plastic packaging.

\section{Waste codes}

Known as European Waste Catalogue (EWC) codes or List of Waste (LOW) codes, these are a legal requirement and should be recorded on all disposed waste containers. They instruct on the content of the bin and how it will be disposed of.

\section{European Waste Catalogue (EWC) waste codes}

\begin{tabular}{|c|c|c|}
\hline & Non-hazardous & Hazardous \\
\hline 180201 & Sharps (except 1802 02) & \\
\hline 180202 & & $\begin{array}{l}\text { Wastes subject to special requirements in order to } \\
\text { prevent infection }\end{array}$ \\
\hline 180203 & $\begin{array}{l}\text { Wastes not subject to special requirements in order } \\
\text { to prevent infection }\end{array}$ & \\
\hline 180205 & & $\begin{array}{l}\text { Chemicals consisting of or containing dangerous } \\
\text { substances }\end{array}$ \\
\hline 180206 & Chemicals other than those mentioned in 180205 & \\
\hline 180207 & & Cytotoxic and cytostatic medicines \\
\hline 180208 & Medicines other than those mentioned in 180207 & \\
\hline
\end{tabular}

In addition to the EWC code, hazardous waste must be defined under one of the Hazardous Property (HP) codes. For veterinary medicines these include:

- HP6 - toxic teratogenic

- HP7 - carcinogenic

- HP9 - infectious

- HP10 - toxic for reproduction

- HP11 - mutagenic.

\section{Whole pharmaceuticals}

These are made up of the following:

- Returned stock

- Out of date stock

- Damaged stock.

\section{Returned stock}

The decision to accept returned medicines will vary on an individual basis and should include consideration of refunds, social responsibility for taking the medicine out of circulation and the practice relationship with the client. It is permissible to reuse returned medicines provided the practice is sure that they have been stored according to the summary of product characteristics (SPC). Damaged or incorrectly stored medicines will need disposal and this will incur a cost if done at the practice; disposal by the client at home falls outside the Waste Regulations.

\section{Out of date stock}

Out of date medicines should always be disposed of and never used. It is illegal to supply or use out of date medicines. For multidose injectable medicines, the broach date of the vial must be recorded and disposal after the designated number of days. This is usually (but not always) 28 days after the broaching. 


\section{Damaged stock}

Damaged stock includes any in-transit damages or spillages and breakages. For spilled medicines, the medicine should be contained with the practice 'spill kit' (sand, sawdust or cat litter), swept into a container, and the content and amount estimated and recorded. The container can then be disposed of into the pharmaceutical waste bin.

\section{Disposal of whole pharmaceuticals}

The medicines should be collected into the 'pharmy bin'. It is important to ensure that solid and liquid medicines are kept separate. There have been several recorded incidences of fires started by chemical reactions within pharmaceutical waste bins. Tablets should be kept within blister packs or the original packaging. If these are not available, tablets of the same medicine should be collected into tablet envelopes or tablet pots before disposal.

\section{Residue pharmaceuticals}

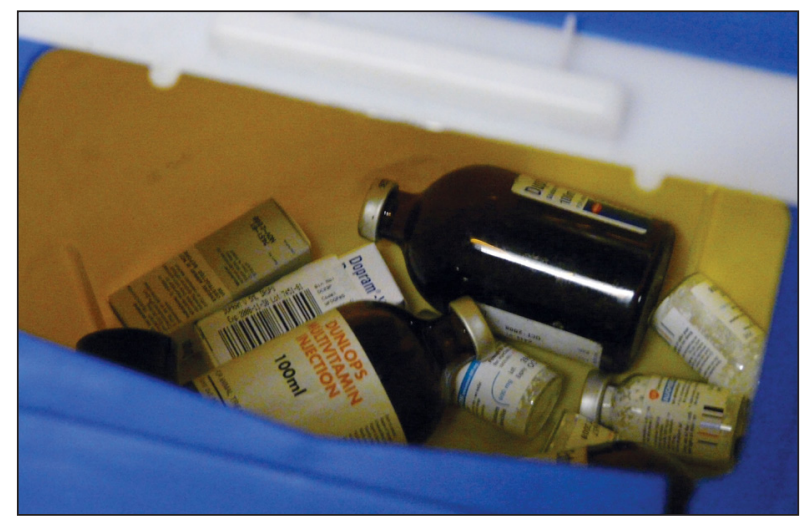

These are waste items that have been contaminated with medicines.

\section{Empty medicinal containers}

This type of waste includes all empty multidose bottles, vaccine vials, medicinal contaminated packaging and contaminated tablet pots. These should be collected into the pharmaceutical waste bin and can be mixed with whole medicines. Only the containers of cytotoxic/cytostatic medicines need to be segregated as hazardous waste. The majority are non-hazardous. A detailed list is not required.

\section{Medicine delivery wastes}

This includes discharged syringes, giving sets, cannulae and catheters that have been medicinally contaminated. All sharps must be detached before disposal.

\section{Sharps/needles}

Advice from the BVA via the Environment Agency states that all sharps should be disposed of as hazardous waste. It is also Environmental Agency advice that the needle is not removed from the syringe body after use and the whole lot is disposed of as 'sharps'. Larger sharps containers are available. However, disposal of sharps and syringes together will prove expensive because charges are usually calculated by volume and/or weight.

Provided the practice has carried out training and a risk assessment, the separation of needle and syringe after use can be considered. The syringe can be segregated into the empty vials pharmaceutical waste bin. The needle needs to be disposed of into the hazardous sharps container.

It should be noted that cytotoxic/cytostatic contaminated sharps and syringes must be further segregated into purple sharps bins. Such waste items should not be moved between branch surgeries.

\section{Controlled Drugs}

Controlled Drugs (CDs) require additional recording and action before disposal. All CDs must be effectively denatured before disposal. This applies to out of date whole medicines; it is not necessary to apply denaturing to residual amounts left in used vials, syringes or needles. It is permitted to open packaging and de-blister to aid denaturing. Denaturing kits are available from veterinary wholesalers. When denaturing Schedule 2 medicines, a witness must be present and sign that the procedure has been carried out. The record of disposal should be entered into the CD Register so that purchase, use and disposal appear in one single record.

Destruction of out of date Schedule 2 CDs, as well as some Schedule 3 CDs, under the prescribing cascade must be witnessed by a Veterinary Medicines Directorate (VMD) inspector, an Assessor of the Royal College of Veterinary Surgeons (RCVS) Practice Standards Scheme (PSS), a veterinary surgeon who is independent of the practice, or a police officer (such as a Controlled Drugs Liaison Officer (CDLO)) in England, Wales and Scotland. In Northern Ireland, destruction of CDs must be witnessed by a person authorized by the Department of Health.

Once mixed with the denaturing agent, the waste can be deposited into the standard pharmaceutical waste bin. It needs to be recorded on the pharmaceutical waste bin list as a denatured CD. Schedule 3, 4 and 5 CDs are not subject to such rigour, but they still need to be denatured prior to disposal. This does not need external witnessing by an authorized person, but it is best practice to record the event witnessed by a member of the practice staff.

\section{Registration for T28 exemption}

Because the denaturing of CDs is, in effect, processing waste, the practice must apply for an exemption from a waste processing licence. This is a free service and available via their website (@). This EA (English) register also has links to the Scottish, Welsh and Northern Irish exemption sites.

(9) See also Controlled Drugs. 


\section{Cytotoxic and cytostatic medicines}

These medicines are deemed to be hazardous waste and will carry variable hazard codes. They all fall under EWC code: 18 02 07. This means that they must be segregated from all other pharmaceuticals and be disposed of by specialist contractors. The items for disposal include unused medicine, used vials, contaminated syringes, needles, cannulae and contaminated protective clothing. It is important that the disposed medicines are defined by their particular hazardous property (HP) code (see earlier).

The following classes of medicines should be included in this classification:

- Cancer chemotherapeutics (e.g. vincristine, epirubicin/pharmorubicin, methotrexate and all similar classes of tumour toxic medicines)

- Antiviral medicines, including interferon

- Ciclosporin medicines in any form

- Certain hormonal preparations (which are teratogenic or toxic to reproduction) including prostaglandins and androgens (e.g. Alizin aglepristone).

These wastes must be segregated into purple containers (the separate sharps bin should have a purple top, the separate pharmaceutical waste bin should have a purple lid or label and the soft waste bag should be purple). The EWC and HP codes must be clearly visible. The waste needs to be consigned to a specialist contractor and a fee is payable to the Environment Agency on disposal. Such waste items should not be moved between branch surgeries. Carriage of cytotoxic and cytostatic waste in unlicensed vehicles is illegal.

In practical terms, it is unlikely that the volume of this type of waste will be high. It is probably sufficient for the practice to have one cytotoxic sharps bin that is used for all such needles, syringes and used vials. Out of date cytotoxic medicines can also be added, provided they are listed and mixing precautions (see earlier) are observed. Where other contaminated items are produced (e.g. giving sets, cannulae and gloves), these too can be disposed of via the cytotoxic sharps bin. For practices producing large volumes of such waste (e.g. oncological specialists), larger volume sharps bins could be considered.

\section{Terminology}

The waste regulations have made some traditional definitions obsolete. Waste from the practice should now be referred to as healthcare waste. Use of the words 'clinical waste' should be avoided as this now carries a legal definition and refers specifically to hazardous waste. Traditionally, pharmaceutical disposal was covered by the DOOP (Destruction of Old Pharmaceutical) Regulations and such waste was called DOOP waste. It is more accurate now to refer to the waste as pharmaceutical waste as a category of healthcare waste. DOOP bins are now pharmaceutical waste bins. It is therefore preferable to stop referring to medicinal waste as DOOP.

\section{Variations in legislation for Scotland}

The above regulations are specific to England and Wales. By and large, the above information is relevant to Scotland. The key difference is the substitution of the word 'special' for 'hazardous', i.e. Scottish 'special waste' is equivalent to English 'hazardous waste'.

Where Scottish waste contractors are giving different advice, it is advised to seek a further opinion from the Scottish Environment Protection Agency (SEPA).

\section{Variations in legislation for Wales}

Natural Resources Wales (NRW) now has responsibility for waste regulation, and may develop variations from the English Environment Agency. So far, the only variant is for registration of T28 exemption.

\section{Variations in legislation for Northern Ireland}

The Northern Ireland Environment Agency (NIEA) are developing their own variation of the waste regulations. Practices are advised to be aware of any regional requirements. 


\section{QUESTIONS}

1. A needle used to deliver a water-based vaccination is disposed of via:
a. A white-topped sharps bin
b. A yellow-topped sharps bin
c. A purple-topped sharps bin
d. A pharmaceutical waste bin

2. What EWC code is used to define the disposal of a half-empty bottle of oxytocin, past its 28th day broach date?
a. 180203
b. 180205
c. 180206
d. 180207

3. The colour orange defines:
a. Non-hazardous waste that must be incinerated
b. Hazardous waste that must be incinerated
c. Non-hazardous waste that can go to land-fill
d. Hazardous waste that needs special treatment before disposal

4. Controlled Drug wastes, once denatured, are disposed of as:
a. Hazardous waste that must be incinerated
b. Non-hazardous waste via the pharmaceutical waste bin
c. Non-hazardous via the offensive waste bin
d. Hazardous in the purple-coloured waste bin

5. Cytotoxic and cytostatic medicines include:
a. Alizin (Aglepristone)
b. Ciclosporins
c. Aciclovir
d. All of these three medicines

$p-\varsigma: q-\nabla: p-\varepsilon ! p-\tau: q-\tau$ SUJMSN $\forall$ 